Article

\title{
Nobiletin Induces Protective Autophagy Accompanied by ER-Stress Mediated Apoptosis in Human Gastric Cancer SNU-16 Cells
}

\author{
Jeong Yong Moon ${ }^{1}$ and Somi Kim Cho ${ }^{1,2, *}$ \\ 1 Subtropical Horticulture Research Institute, Jeju National University, Jeju 63243, Korea; \\ owenmjy@jejunu.ac.kr \\ 2 Faculty of Biotechnology, College of Applied Life Sciences, SARI, Jeju National University, Jeju 63243, Korea \\ * Correspondence: phd.kim.somi@gmail.com; Tel.: +82-64-754-3348; Fax: +82-64-756-3351
}

Academic Editors: Arturo San Feliciano and Celestino Santos-Buelga

Received: 10 May 2016; Accepted: 8 July 2016; Published: 14 July 2016

\begin{abstract}
Nobiletin, a major component of citrus fruits, is a polymethoxyflavone derivative that exhibits anticancer activity against several forms of cancer, including SNU-16 human gastric cancer cells. To explore the nobiletin-induced cell death mechanism, we examined the changes in protein expression caused by nobiletin in human gastric cancer SNU-16 cells by means of two-dimensional gel electrophoresis (2-DGE), followed by peptide mass fingerprinting (PMF) analysis. Seventeen of 20 selected protein spots were successfully identified, including nine upregulated and eight downregulated proteins. In nobiletin-treated SNU-16 cells the glucose-regulated protein $78 \mathrm{kDa}$ (GRP78) mRNA level was induced most significantly among six proteins related to cell survival and death. Western blot analysis was used to confirm the expression of GRP78 protein. We detected increases in the levels of the ER-stress related proteins inositol requiring enzyme 1 alpha (IRE1- $\alpha$ ), activating transcription factor 4 (ATF-4), and C/EBP homology protein (CHOP), as well as GRP78, in response to nobiletin in SNU-16 cells. Furthermore, the ER stress-mediated apoptotic protein caspase- 4 was proteolytically activated by nobiletin. Pretreatment with chloroquine, an autophagy inhibitor, strongly augmented apoptosis in SNU-16 cells, as evidenced by decreased cell viability, an increased number of sub-G1 phase cells and increased levels of cleaved PARP. Our results suggest that nobiletin-induced apoptosis in SNU-16 cells is mediated by pathways involving intracellular ER stress-mediated protective autophagy. Thus, the combination of nobiletin and an autophagy inhibitor could be a promising treatment for gastric cancer patients.
\end{abstract}

Keywords: apoptosis; autophagy; ER stress; GRP78; nobiletin; SNU-16

\section{Introduction}

Nobiletin $\left(5,6,7,8,3^{\prime}, 4^{\prime}\right.$-hexamethoxyflavone) is a citrus fruit-derived polymethoxyflavonoid [1] that suppresses matrix metalloproteinase (MMP)-7 expression, presumably by blocking AP-1 activity [2]. Nobiletin can directly inhibit mitogen-activated protein/extracellular signal-regulated kinase kinase (MEK) activity and decrease the sequential phosphorylation of extracellular signal-regulated kinases (ERK), leading to antitumor activity by suppressing MMP expression in HT-1080 cells [3]. We previously demonstrated that nobiletin induced apoptosis and had synergistic anticancer effects with 5-fluorouracil in p53-mutated SNU-16 cells [4]. Despite these findings, the target proteins in nobiletin-treated cancer cells have not been identified and the mechanisms underlying the anticancer properties of nobiletin remain unclear. To facilitate more effective therapeutic approaches, we used two-dimensional gel electrophoresis (2-DGE) and peptide mass fingerprinting (PMF) proteomic analysis to identify proteins involved in the anticancer mechanisms of nobiletin using the human gastric cell line SNU-16. 
The endoplasmic reticulum (ER) performs several functions, including protein folding and transport, and regulation of the intracellular calcium concentration. Cells trigger the unfolded protein response (UPR) as a self-protective mechanism upon the disruption of ER functions via the accumulation of unfolded/misfolded proteins in the ER [5]. Under normal conditions, the ER stress sensors inositol-requiring- $1 \alpha$ (IRE1- $\alpha$ ), pancreatic ER kinase or PKR-like ER kinase (PERK), and activating transcription factor 6 (ATF6) bind to immunoglobulin heavy chain binding protein (BiP)/GRP78. These sensors are released from BiP/GRP78 under conditions of ER stress and transfer downstream signals to the cytoplasm. IRE1- $\alpha$, a transmembrane protein in the endoplasmic reticulum (ER), which functions as a sensor and transducer of ER stress, activates X-box-binding protein-1 (XBP-1) and several UPR target genes. ER stress-mediated apoptosis is triggered by activation of the ER membrane resident caspase-12 (mice) and caspase-4 (humans) and the induction of C/EBP homology protein (CHOP) [6]. ER stress-induced apoptotic signaling has been studied to identify potential targets for therapeutic intervention in diseases associated with ER stress [7]. The CHOP-mediated downregulation of Bcl-2 can favorably influence pro-apoptotic Bcl-2 family proteins and cell death [8,9].

Autophagy is a cellular defense mechanism involving the degradation and recycling of cytoplasmic constituents. Several cell signaling pathways regulate autophagy, including those involving phosphatidyl inositol 3-kinase (PI3K)/Akt/mammalian target of rapamycin (mTOR). Studies have shown that the inhibition of Akt and its downstream target mTOR contribute to autophagy initiation [10]. During autophagy, autophagosomes engulf cytoplasmic components, including cytosolic proteins and organelles. Concomitantly, a cytosolic form of LC3 (LC3-I) is conjugated to phosphatidylethanolamine to form LC3-phosphatidylethanolamine conjugate (LC3-II), which is recruited to autophagosomal membranes [11].

In the present study, we examined the changes in protein expression caused by nobiletin in human gastric cancer SNU-16 cells using 2-DGE and proteomic analysis to explore the mechanism of nobiletin-induced cell death. The ER-stress-related protein GRP78 was identified as a potential target for nobiletin, and our results demonstrate that nobiletin induces ER stress-mediated apoptosis in SNU-16 cells. Moreover, protective autophagy was followed by apoptosis. Thus, we propose that combined treatment with nobiletin and an autophagy inhibitor could be a promising treatment for gastric cancer patients.

\section{Results}

\subsection{2-DGE and Protein Identification by MS}

Quantitative and qualitative analyses were performed twice, and the change in expression was considered significant if the intensity of the corresponding spot was reproducibly different and increased or decreased in relative volume between the cells treated with $50 \mu \mathrm{M}$ nobiletin and DMSO (negative control) for $24 \mathrm{~h}$. The treatment time was chosen based on the finding that $24 \mathrm{~h}$-treated SNU-16 cells had $65.30 \% \pm 9.76 \%$ viability (data not shown) compared to $41.65 \%$ viability of the cell treated cells for $48 \mathrm{~h}$ [4]. Sixty-two different spots between nobiletin treatment and the negative control were identified by repeated 2-DGE analysis. We excluded spots that were too weak and selected 20 spots that were dense on both gels. Seventeen of 20 selected protein spots were successfully identified (Figure 1), including nine upregulated and eight downregulated proteins (Table 1). mRNA levels of the six proteins related to cell survival and death-including the Rho GDP dissociation inhibitor 1 (RhoGDI), glucose-regulated protein $78 \mathrm{kDa}$ (GRP78), thioredoxin domain-containing protein 5 (TXNDC5), COMM domain-containing protein 9 (COMD9), eukaryotic translation initiation factor 4E (EIF4E), and peroxiredoxin 3 (PRDX3) - were analyzed by RT-PCR. Among these, the GRP78 mRNA level was most significantly induced in nobiletin-treated SNU-16 cells (Figure 2). Next, the changes in GRP78 levels in SNU-16 cells were confirmed by western blotting. 
A

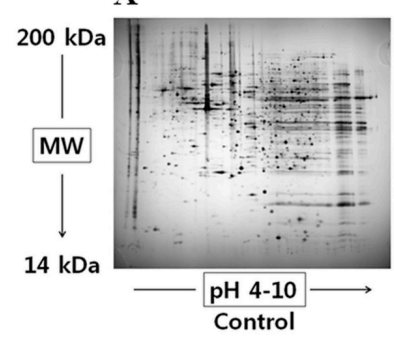

B

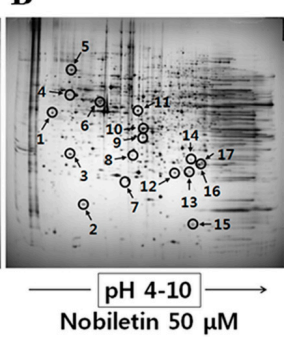

Figure 1. Representative protein maps from human gastric cancer SNU-16 cells that were treated with (A) DMSO or (B) $50 \mu \mathrm{M}$ nobiletin for $24 \mathrm{~h}$. Spots with arrows represent proteins that changed their expression after nobiletin treatment; the PMF-based identification of these spots is summarized in Table 1.
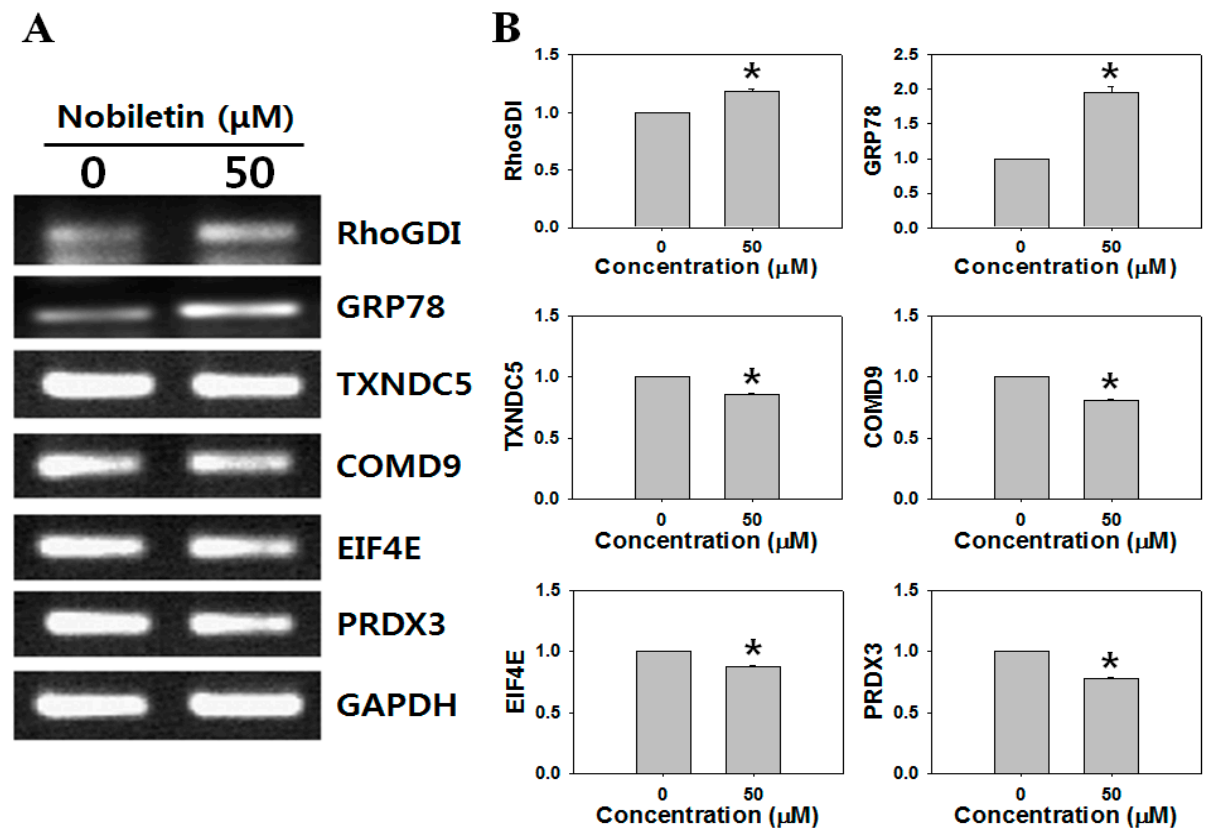

Figure 2. Effect of nobiletin on mRNA levels in SNU-16 cells. (A) Expression levels of six genes related to cell survival and death were determined by RT-PCR in SNU-16 cells treated with or without $50 \mu \mathrm{M}$ nobiletin for $24 \mathrm{~h}$; (B) The intensities of RT-PCR bands were quantified using ImageJ software. ${ }^{*} p<0.01$.

Table 1. Proteins from nobiletin-treated SNU-16 cells identified by PMF spectrometry of spots excised from two-dimensional gels.

\begin{tabular}{clccc}
\hline No. $^{\mathbf{a}}$ & \multicolumn{1}{c}{ Identified Protein } & Score & $\mathbf{M W}^{\mathbf{b}}(\mathbf{D a}) / \mathbf{P I}^{\mathbf{c}}$ & Fold Change $^{\mathbf{d}}$ \\
\hline 1 & Spermine synthase & 120 & $41698 / 4.87$ & 4.5 \\
\hline 2 & Chain B, histocompatibility antigen Hla-Dm & 67 & $21972 / 6.70$ & 3.6 \\
\hline 3 & Rho GDP-dissociation inhibitor 1 & 135 & $23250 / 5.02$ & 1.9 \\
\hline 4 & $\begin{array}{l}\text { Mitochondrial ATP synthase, H-transporting } \\
\text { F1 complex beta subunit }\end{array}$ & 136 & $48083 / 4.95$ & \multirow{2}{*}{3.2} \\
\hline 5 & 78 kDa glucose-regulated protein & 241 & $72402 / 5.07$ & 6.4 \\
\hline 6 & TXNDC5 protein & 233 & $41028 / 5.57$ & 5.1 \\
\hline 7 & COMM domain-containing protein 9 & 91 & $17436 / 6.41$ & 0.3 \\
\hline
\end{tabular}


Table 1. Cont.

\begin{tabular}{clccc}
\hline No. $^{\mathbf{a}}$ & \multicolumn{1}{c}{ Identified Protein } & Score & $\mathbf{M W}^{\mathbf{b}} \mathbf{( D a ) / \mathbf { P I } ^ { \mathbf { c } }}$ & Fold Change $^{\mathbf{d}}$ \\
\hline 8 & Eukaryotic translation initiation factor 4E & 73 & $15290 / 6.73$ & 0.4 \\
\hline 9 & $\begin{array}{l}\text { Chain A, the high resolution structure of } \\
\text { annexin Iii shows differences with annexin V }\end{array}$ & 183 & $36480 / 5.63$ & 4.2 \\
\hline 10 & $\begin{array}{l}\text { Capping protein (actin filament) muscle } \\
\text { Z-line, alpha 2 }\end{array}$ & 93 & $31898 / 6.46$ & 56.1 \\
\hline 11 & EF-hand calcium binding domain 6 & 85 & $48889 / 9.67$ & 2.4 \\
\hline 12 & Peroxiredoxin 3 & 66 & $11158 / 6.06$ & 0.8 \\
\hline 13 & Proteasome subunit beta type-3 & 71 & $23219 / 6.14$ & 0.7 \\
\hline 14 & $\begin{array}{l}\text { Chain A, crystal structure of the protein } \\
\text { disulfide isomerase-related chaperone Erp29 }\end{array}$ & 66 & $27220 / 7.07$ & 0.6 \\
\hline 15 & Fatty acid-binding protein & 64 & $15497 / 6.60$ & 0.6 \\
\hline 16 & Peroxiredoxin-5 & 240 & $25133 / 6.00$ & 0.6 \\
\hline 17 & Proteasome subunit alpha type-6 & 133 & $27838 / 6.34$ & 0.6 \\
\hline
\end{tabular}

${ }^{a}$ No: spot number; ${ }^{b}$ MW: molecular weight; ${ }^{c}$ PI: isoelectric point; ${ }^{d}$ Fold change calculated dividing the $\%$ (vol) from the control gel by that from the nobiletin-treated gel.

\subsection{Nobiletin Induced ER Stress-Mediated Apoptosis}

GRP78 regulates a variety of biological functions, including protein folding, the activation of transmembrane ER stress sensors, and cell survival [12]. Importantly, GRP78 signaling is crucial for cell survival/apoptosis via various signaling pathways $[13,14]$. In addition, previous reports found that nobiletin associated with ER stress by upregulated expression of DDIT3 (DNA-damage-inducible transcript 3, also known as CHOP) and TRIB3 (tribbles homolog 3 protein, also known as TRB3) genes and proteins, which are well known to contribute to apoptosis caused by ER stress, in SK-N-SH human neuroblastoma, HuH-7 human hepatoma, and 3Y1 rat fibroblast cell lines [15-17]. Therefore, we investigated whether ER stress was involved in response to nobiletin treatment in SNU-16 cells. XBP-1 mRNA is constitutively expressed at a low level as an intron-containing precursor mRNA, unspliced XBP-1 (XBP-1u), which is subject to an inositol-requiring-1 $\alpha$ (IRE1- $\alpha$ )-mediated splicing reaction upon ER stress to produce the active form of XBP-1 mRNA, a spliced form of XBP-1 (XBP-1s) [18].

Excision of a 26-nucleotide-long intron creates XBP-1s, resulting in expression of an active and stable transcription factor that regulates transcription of target genes involved in protein folding and ER-associated degradation [19]. As shown in Figure 3A,B, the level of the spliced form of XBP-1 (XBP-1s) was significantly increased by nobiletin treatment, suggesting that ER stress is involved in the response to nobiletin. Next, we determined whether ER stress-mediated apoptosis is induced in response to nobiletin treatment. As shown in Figure 3C,D, the levels of the ER-stress markers inositol-requiring- $1 \alpha$ (IRE1- $\alpha$ ), activating transcription factor 4 (ATF-4), and C/EBP homology protein (CHOP) were increased, and the level of inactive procaspase-4 was decreased. The cleaved form of caspase- 4 was not detected even though we have tried western blot of caspase- 4 many times. We speculate that this may be due to the low level of caspase-4 in the cell since Tatsuta et al. [20] also reported the degradation of procaspase- 4 as a sign of namely activation of caspase- 4 . As proteolytic cleavage of caspase-4 and upregulation of CHOP are reportedly involved in ER stress-mediated apoptosis [6], these results suggest that nobiletin induces ER stress-mediated apoptosis in SNU-16 cells. 
A

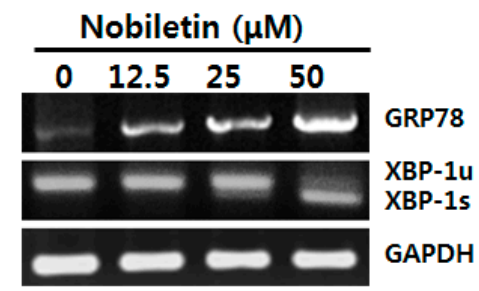

C
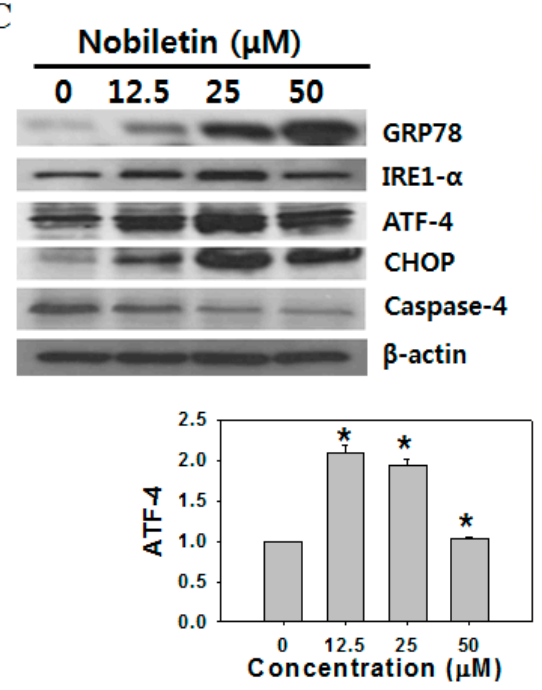

B

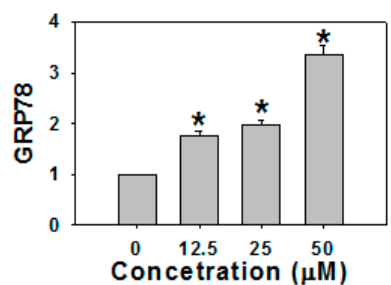

D
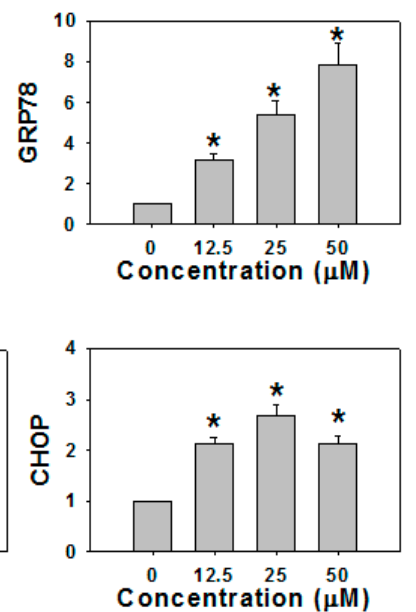
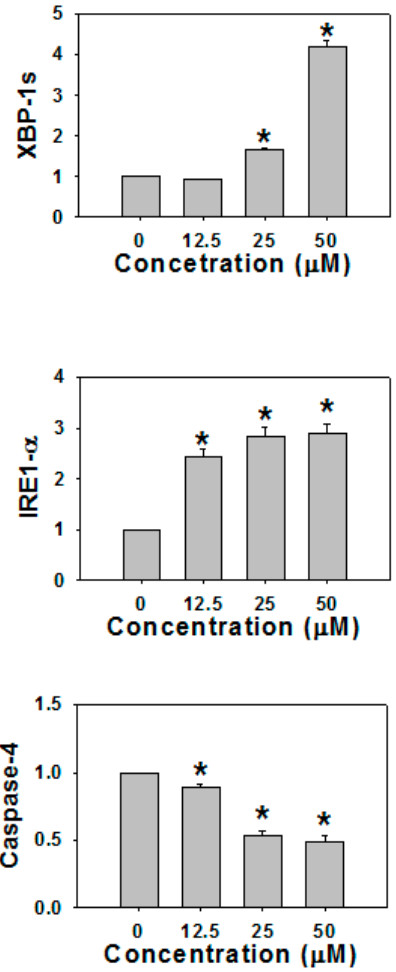

Concetration $(\mu \mathrm{M})$

Figure 3. Effect of nobiletin on the expression of ER stress-related genes and proteins. (A) GRP78 expression and the splicing of endogenous XBP1 (XBP1u, unspliced XBP1; XBP1s, spliced XBP1) was examined by RT-PCR in SNU-16 cells treated with various concentrations of nobiletin for $24 \mathrm{~h}$; (B) The intensities of RT-PCR bands were quantified using the ImageJ software; (C) ER stress- related protein expression was analyzed by western blotting in SNU-16 cells treated with various concentrations of nobiletin for $24 \mathrm{~h}$; (D) The intensities of western blot bands were quantified using the ImageJ software. Data represent the means \pm SD of at least three independent experiments. ${ }^{*}$ Compared with the vehicle group, $p<0.01$.

\subsection{Nobiletin Induced Autophagy in SNU-16 Cells}

Recent studies show that autophagy plays key roles in cancer treatment and is associated with apoptosis [21]. Furthermore, numerous chemotherapeutic drugs have been found to induce cellular autophagy [22,23]. To test whether nobiletin-induced apoptosis can induce autophagy, we examined the levels of Akt/mTOR signaling proteins, either in phosphorylated (activated) or unphosphorylated forms, by western blotting. PI3K/Akt and the downstream mTOR play important roles in regulating cell proliferation, cell cycle, and are key regulators of autophagy initiation [24]. Nobiletin treatment caused a significant decrease in phosphorylated Akt and mTOR, and it increased the ratio of LC3B II/LC3B I and decreased the level of p62, indicating that p62 is degraded by autophagy through a direct interaction with LC3 (Figure 4A,B). 
A

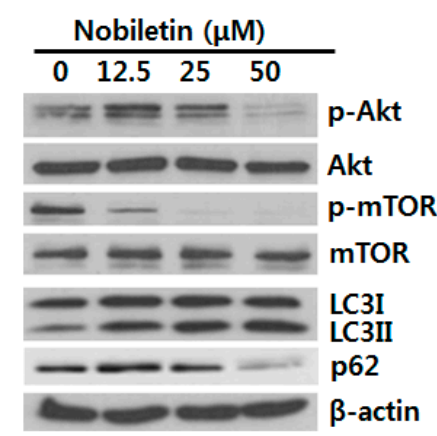

C

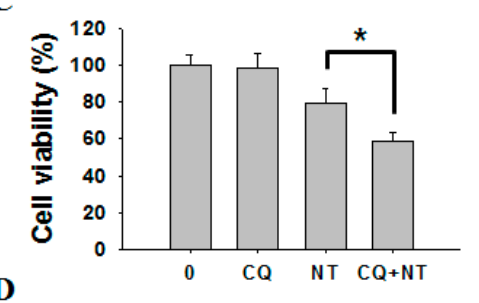

D

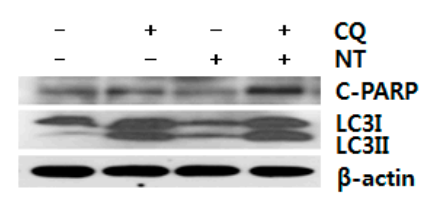

B
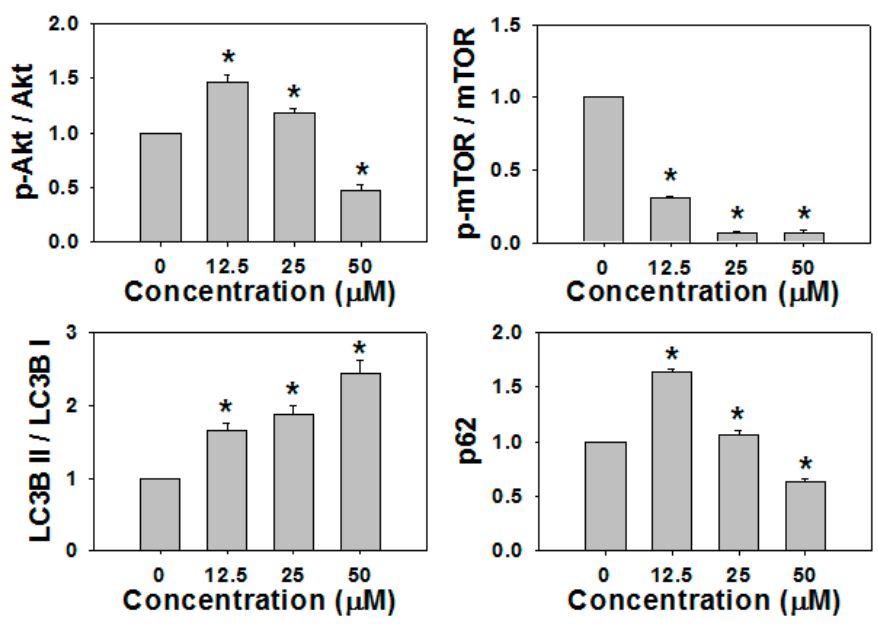

$\mathbf{E}$
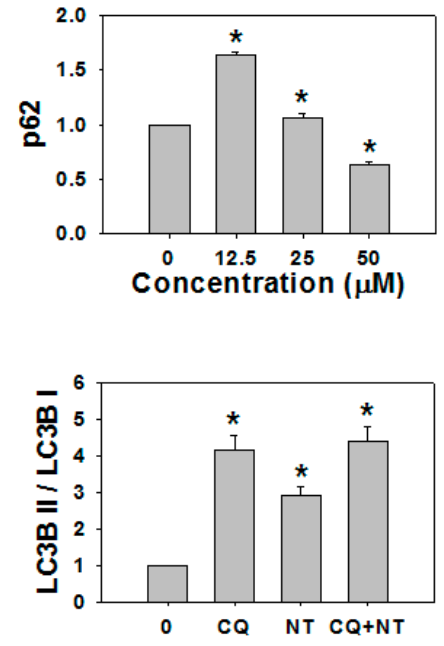

Figure 4. Autophagy induction due to nobiletin and inhibition of autophagy enhance the anticancer activity of nobiletin. (A) Western blotting for Akt, p-Akt, mTOR, p-mTOR, LC3, p62, and $\beta$-actin after treatment of cells with the indicated concentrations of nobiletin for $24 \mathrm{~h}$; (B) The intensities of western blot bands were quantified using ImageJ software. ${ }^{*} p<0.01$; (C) Cell viability (MTT) assay and (D) western blotting were performed after pretreatment with (+) or without (-) $40 \mu \mathrm{M}$ chloroquine (CQ) for $2 \mathrm{~h}$ followed by treatment with $25 \mu \mathrm{M}$ nobiletin (NT) for $24 \mathrm{~h}$; (E) The intensities of western blot bands were quantified using ImageJ software. ${ }^{*} p<0.01$.

\subsection{Inhibition of Autophagy Increases Nobiletin-Induced Apoptosis}

Autophagy may have a protective effect on tumor cells and therapy-induced cell death can be potentiated through autophagy inhibition [25]; thus, we determined whether the autophagy signal induced by nobiletin was pro-survival or pro-death. Cells were treated with chloroquine (CQ), which inhibits the fusion of autophagosomes and lysosomes, for $2 \mathrm{~h}$ before nobiletin (NT) treatment. As shown in Figure 4C, the proliferation of NT-treated SNU-16 cells was significantly reduced when cells were pre-treated with CQ, while CQ treatment alone did not affect cell viability. Western blotting revealed that NT increased cleaved PARP in the presence of CQ (Figure 4D,E). We also examined the sub-G1 population in SNU-16 cells pretreated with CQ followed by nobiletin treatment. When cells were treated with nobiletin alone for $24 \mathrm{~h}, 17.2 \% \pm 2.9 \%$ of the cells were in sub-G1 phase (Table 2). In cells pretreated with CQ and then treated with nobiletin, the sub-G1 population increased to $23.0 \% \pm 3.1 \%$. These findings indicate that nobiletin-induced autophagy plays a protective role against apoptosis and that the inhibition of nobiletin-induced autophagy could enhance apoptosis in SNU-16 cells. 
Table 2. The percentage of SNU-16 cells in different phases of the cell cycle after nobiletin treatment with/without CQ for $24 \mathrm{~h}$.

\begin{tabular}{ccccc}
\hline \multirow{2}{*}{ Treatment } & \multicolumn{5}{c}{ Phase (\%) } \\
\cline { 2 - 5 } & Sub-G1 & G1 & S & G2/M \\
\hline Control & $7.9 \pm 4.7$ & $55.3 \pm 2.4$ & $11.6 \pm 1.1$ & $25.5 \pm 5.3$ \\
CQ $^{\mathrm{a}}$ alone & $9.6 \pm 2.8$ & $55.1 \pm 4.9$ & $11.5 \pm 2.4$ & $24.2 \pm 2.7$ \\
Nobiletin $^{\mathrm{b}}$ alone & $17.2 \pm 2.9 *$ & $63.0 \pm 1.4$ & $4.2 \pm 0.9$ & $15.8 \pm 3.3$ \\
Nobiletin + CQ $^{*}$ & $23.0 \pm 3.1^{*}$ & $54.4 \pm 6.1$ & $6.2 \pm 2.4$ & $16.6 \pm 3.6$ \\
\hline
\end{tabular}

The results are presented as means \pm standard deviation of at least three independent experiments. ${ }^{*} p<0.01$.

${ }^{\mathrm{a}}$ Chloroquine (CQ) concentration; $40 \mu \mathrm{M}$ and ${ }^{\mathrm{b}}$ nobiletin concentration; $25 \mu \mathrm{M}$.

\section{Discussion}

We identified the cellular effectors of nobiletin using 2-DGE, which may provide insight into the intracellular cell death signaling and underlying mechanism exerted by nobiletin. Our proteomic screen revealed dramatic differences between the nobiletin-treated cells and controls (Table 1). We hypothesized that proteins related to cell proliferation and survival would be identified since we previously reported that nobiletin induced apoptosis in SNU-16 cells [4]. We identified 17 proteins, including nine upregulated and eight downregulated proteins. Among these proteins, six are reportedly related to cell survival and death; i.e., RhoGDI, GRP78, TXNDC5, COMD9, EIF4E, and PRDX3, which reportedly affect Rho GTPase activity, ER stress, cancer progression, NF- $\mathrm{BB}$ suppression, cell growth, cell cycle progression, and apoptosis [26-31]. RT-PCR revealed that GRP78 was the most strongly induced of all of the nobiletin-responsive proteins (Figure 2). GRP78, or BiP, is a major ER-localized chaperone that is conserved from yeast to humans [32,33]. GRP78 is highly expressed under stressful conditions, including low glucose, low oxygen, and low calcium, and it is responsible for maintaining ER stability and cell protection [34]. GRP78 is closely associated with carcinogenesis and tumor development, differentiation, and drug resistance [35]. The significant increase in GRP78 caused by nobiletin suggests the involvement of ER stress in the mechanism of SNU-16 cell death. As shown in Figure 3, IRE1- $\alpha$, ATF-4, CHOP, and caspase-4, which are responsible for UPR signaling, were significantly activated.

The ER plays an important role in protein folding, assembly, modification, and transport. UPRs can occur in most tumor cells, and they can promote tumor cell growth and induce GRP78 expression in the ER [36]. The central feature of this adaptive response was suggested to be maintenance of the expression of proteins that facilitate cell survival (e.g., GRP78). In addition, PI3K/Akt is a critical mediator of growth factor-induced cell survival and can suppress cell death induced by a variety of apoptotic stimuli [37]. Inhibition of the Akt/mTOR pathway is correlated with autophagy induction [38,39], and ER stress-induced autophagy is responsible for the effective removal of toxic proteins from the ER and cell protection [40].

However, as indicated in Figure 4A,B, the p-Akt level was increased by application of $12.5 \mu \mathrm{M}$ nobiletin. This is reminiscent of recent studies that nobiletin can enhance the circadian clock which is known to regulate insulin signaling, specifically AKT activation [41,42]. Nobiletin potently protects against metabolic syndrome in a clock-dependent manner and it remodels circadian and metabolic gene expression [43]. On the other hand, a negative feedback loop has been described whereby mTOR/S6K1 activation attenuates PI3K signaling by suppressing insulin receptor substrate-1 (IRS1) function, a mediator of insulin receptor-dependent activation of PI3K [44]. It has been proposed that mTORC1 inhibition relieves inhibition of the PI3K pathway thorough inactivation of S6K1, thereby activating Akt in low concentration of nobiletin [45].

During the initial stages of autophagy, cellular proteins, organelles, and the cytoplasm are sequestered and engulfed by intracellular double-membrane-bound structures called autophagosomes. In turn, autophagosomes fuse with lysosomes, and their contents are degraded by lysosomal hydrolases [46]. Because p62 binds to ubiquitin and to LC3, it is both a selective autophagy substrate 
and a cargo receptor for autophagic degradation of ubiquitinated targets [47]. p62 forms cytosolic inclusion bodies distinct from aggresomes, which contain ubiquitinated protein aggregates that are subsequently degraded by autophagy [48]. Therefore, p62 is considered to act as a receptor for ubiquitinated proteins, which it sequesters into the autophagosome, and impaired autophagy is accompanied by accumulation of p62. Also, p62 is a stress response protein that is strongly induced at the mRNA and protein levels by exposure to oxidants, sodium arsenite, cadmium, ionophores, and proteasome inhibitors [49]. Our results demonstrate an immediate increase in the level of p62 during the initial stages of autophagy (12.5 $\mu \mathrm{M}$ nobiletin) followed by a gradual decrease in a dose-dependent manner, demonstrating that eventually autophagy is accompanied by degradation of p62 following application of nobiletin. Therefore, the combination of nobiletin with an autophagy inhibitor may improve the therapeutic outcome in gastric cancer.

\section{Materials and Methods}

\subsection{Chemicals and Reagents}

Nobiletin, propidium iodide (PI), and anti- $\beta$-actin antibodies were purchased from Sigma-Aldrich (St. Louis, MO, USA). RPMI-1640 medium, trypsin/EDTA, fetal bovine serum (FBS), penicillin, streptomycin, goat anti-rabbit IgG, and goat anti-mouse IgG secondary antibodies were obtained from Life Technologies (Carlsbad, CA, USA). Dimethyl sulfoxide (DMSO) and MTT were purchased from Amresco (Solon, OH, USA). Antibodies against various proteins for Western blotting such as cleaved PARP, caspase-4, IRE1- $\alpha$, ATF-4, CHOP, p-Akt, Akt, p-mTOR, mTOR, and LC3B were obtained from Cell Signaling Technology (Danvers, MA, USA). Anti-GRP78 antibodies were purchased from Santa Cruz Biotechnology (Santa Cruz, CA, USA).

\subsection{Cell Culture}

SNU-16 cells were maintained at $37{ }^{\circ} \mathrm{C}$ in a humidified atmosphere containing $5 \% \mathrm{CO}_{2}$ in RPMI-1640 medium containing 10\% heat-inactivated FBS, $100 \mathrm{U} / \mathrm{mL}$ penicillin, and $100 \mu \mathrm{g} / \mathrm{mL}$ streptomycin. Exponentially growing cells were treated with various concentrations of the solvent fractions as indicated.

\subsection{2-DGE Reagents}

Urea, thiourea, 3-[(3-cholamidopropy) dimethyammonio]-1-propanesulfonate (CHAPS), dithio-threitol (DTT), benzamidine, Bradford solution, acrylamide, iodoacetamide, bisacrylamide, SDS, acetonitrile, trifluoroacetic acid, and $\alpha$-cyano-4-hydroxycinnamic acid were purchased from Sigma-Aldrich (electrophoresis grade, ACS reagents, Ultrapure). Pharmalyte (pH 3.5-10) was obtained from Amersham Biosciences (Piscataway, NJ, USA) and IPG DryStrips (pH 4-10 NL, $24 \mathrm{~cm}$ ) were obtained from Genomine (Gyeongsangbuk-do, Korea). Modified porcine trypsin (sequencing grade) was purchased from Promega (Madison, WI, USA).

\subsection{2-DGE}

IPG strips were equilibrated for $12-16 \mathrm{~h}$ with $7 \mathrm{M}$ urea, $2 \mathrm{M}$ thiourea containing $2 \%$ CHAPS, $1 \%$ DTT, and $1 \%$ Pharmalyte, and loaded with $200 \mu \mathrm{g}$ of sample. Isoelectric focusing (IEF) was performed at $20^{\circ} \mathrm{C}$ using a Multiphor II electrophoresis unit and EPS $3500 \mathrm{XL}$ power supply (Amersham Biosciences) following the manufacturer's instructions. For IEF, the voltage was linearly increased from 150 to $3500 \mathrm{~V}$ over $3 \mathrm{~h}$ for sample entry followed by a constant voltage ( $3500 \mathrm{~V})$ with focusing complete after $96 \mathrm{kVh}$. Prior to the second dimension, the strips were incubated for $10 \mathrm{~min}$ in equilibration buffer (50 mM Tris-HCl, pH 6.8, containing $6 \mathrm{M}$ urea, $2 \%$ SDS, and 30\% glycerol) first with 1\% DTT and then with $2.5 \%$ iodoacetamide. Equilibrated strips were inserted onto SDS-polyacrylamide gels $(20 \times 24 \mathrm{~cm}$, $10 \%-16 \%$ ). SDS-PAGE was performed using the Hoefer DALT 2D system (Amersham Biosciences) following the manufacturer's instructions. The two-dimensional gels were run at $20^{\circ} \mathrm{C}$ for $1700 \mathrm{Vh}$ 
then silver-stained as described, except that the fixation and sensitization steps with glutaraldehyde were omitted [50].

\subsection{Image Analysis}

A quantitative analysis of digitized images was performed using PDQuest (version 7.0; Bio-Rad, Hercules, CA, USA) software according to the manufacturer's protocols. The quantity of each spot was normalized by the total valid spot intensity. Protein spots were selected based on significant expression variation deviating more than twofold in expression level compared with control or normal samples.

\subsection{Peptide Mass Fingerprinting (PMF)}

For protein identification using PMF, protein spots were excised, digested with trypsin (Promega, Madison, WI, USA), mixed with $\alpha$-cyano-4-hydroxycinnamic acid in $50 \%$ acetonitrile $/ 0.1 \%$ TFA, and subjected to matrix-assisted laser desorption/ionization- time-of-flight (MALDI-TOF) analysis (Ettan MALDI-TOF Pro; Amersham Biosciences) as described previously [51]. Spectra were collected from 350 shots per spectrum over the $600-3000 \mathrm{~m} / \mathrm{z}$ range and calibrated by two-point internal calibration using trypsin autodigestion peaks $(\mathrm{m} / z 842.5099$ and 2211.1046). The peak list was generated using the Ettan MALDI-TOF Pro Evaluation Module (version 2.0.16; GE Healthcare, Little Chalfont, UK). The thresholds used for peak-picking were 5000 for minimum resolution of monoisotopic masses and 2.5 for $\mathrm{S} / \mathrm{N}$. The search program MASCOT, developed by Matrix Science (Boston, MA, USA), was used for protein identification. The following parameters were used for the database search: trypsin as the cleaving enzyme, a maximum of one missed cleavage, iodoacetamide (Cys) as a complete modification, oxidation (Met) as a partial modification, monoisotopic masses, and a mass tolerance of \pm 0.1 Da. Probability scoring was used as PMF acceptance criteria.

\subsection{Reverse Transcription-Polymerase Chain Reaction (RT-PCR)}

Total RNA was extracted using TRIzol reagent (Invitrogen, Frederick, MO, USA) and precipitated in ethanol. cDNA synthesis was performed with $1 \mu \mathrm{g}$ of total RNA by reverse transcription (Promega). The primers used were: Rho GDP dissociation inhibitor 1 (RhoGDI) [5'-GAGCCTGCGAAAGTACAAGG-3' (sense), and 5'-TCCTTCAGCACAAACGACTG-3' (antisense)]; glucose-regulated protein $78 \mathrm{kDa}$ (GRP78) [5'-CTCCTGAAGGGGAACGTCTG-3' (sense), and $5^{\prime}$-AACACTTTCTGGACGGGCTT-3' (antisense)]; thioredoxin domain-containing protein 5 (TXNDC5) [5'-GCACAAGGCGACCACTTTAT-3' (sense), and 5' -ATCCCGCTTTCCCTTGTACT-3' (antisense)]; COMM domain-containing protein 9 (COMD9) [5'-CCACCAAAACCTCAAAAACC-3' (sense), and $5^{\prime}$-AGGCTGGGATCTTCTTGGAT-3' (antisense)]; eukaryotic translation initiation factor 4E (EIF4E) [5'-CAGATGGGCACTCTGGTTTT-3' (sense), and 5'-CTCCCCGTTTGTTTTTCTCA-3' (antisense)]; peroxiredoxin 3 (PRDX3) [5'-GTTGTCGCAGTCTCAGTGGA-3' (sense), and $5^{\prime}$-GACGCT CAAATGCTTGATGA-3' (antisense)]; XBP-1 [5'-TTACGAGAGAAAACTCATGGCC-3' (sense), and 5'-GGGTCCAAGTTGTCCAGAATGC-3' (antisense)]; and GAPDH [5'-GAGAAGGCTGGGGCTC ATTT- $3^{\prime}$ (sense), and $5^{\prime}$-AGTGATGGCATGGACTGTGG-3' (antisense)]. The RT-PCR conditions were $95{ }^{\circ} \mathrm{C}$ pre-denaturation for $5 \mathrm{~min}$, followed by $95^{\circ} \mathrm{C}$ denaturation for $40 \mathrm{~s}, 55-60{ }^{\circ} \mathrm{C}$ annealing for $30 \mathrm{~s}$, and $72{ }^{\circ} \mathrm{C}$ extension for $40 \mathrm{~s}$, for a total of 35 cycles.

\subsection{Western Blotting}

Harvested cells were washed with PBS and then lysed with RIPA lysis buffer containing protease inhibitor cocktail (BioVision, Milpitas, CA, USA) and PMSF. Protein concentrations were determined using BCATM Protein Assay Reagent (Pierce, IL, USA). Equal amounts of protein were separated by $7.5 \%-15 \%$ SDS-PAGE and transferred to a polyvinylidene difluoride (PVDF) membrane (Merck Millipore, Darmstadt, Germany) using glycine transfer buffer (192 mM glycine, $25 \mathrm{mM}$ Tris-HCl ( $\mathrm{pH} 8.8)$, and 20\% (v/v) methanol). After blocking with 5\% skim milk, the membrane was incubated for $2 \mathrm{~h}$ with primary antibodies and then for $30 \mathrm{~min}$ with secondary antibodies in milk containing 
Tris-buffered saline and 0.1\% Tween 20. The membrane was then exposed to X-ray film (AGFA, Mortsel, Belgium) and the protein bands were detected using the WEST-ZOL ${ }^{\circledR}$ plus Western Blot Detection System (iNtRON, Gyeonggi-do, Korea).

\subsection{Cell Viability Assay}

Cell growth inhibition was examined using an MTT assay. SNU-16 was seeded in 96-well culture plates $\left(5 \times 10^{4}\right.$ cells $\left./ \mathrm{mL}\right)$. After incubation overnight, the cells were treated with $40 \mu \mathrm{M}$ chloroquine (CQ) and $25 \mu \mathrm{M}$ nobiletin (NT). Next, $0.1 \mathrm{mg}$ of MTT was added to each well and the cells were incubated at $37^{\circ} \mathrm{C}$ for $4 \mathrm{~h}$. The medium was removed and $150 \mu \mathrm{L}$ of DMSO was then added to each well to dissolve the formazan crystals. The absorbance at $570 \mathrm{~nm}$ was measured using a microplate reader (Tecan, Salzburg, Austria).

\subsection{Flow Cytometry}

For cell cycle distribution analysis, cells $\left(5 \times 10^{4} \mathrm{~mL}\right)$ were plated and left untreated or treated with samples for $24 \mathrm{~h}$. The cells were then collected, fixed in 70\% ethanol, washed in $2 \mathrm{mM}$ EDTA in phosphate-buffered saline (PBS), resuspended in $1 \mathrm{~mL}$ of PBS containing $1 \mathrm{mg} / \mathrm{mL}$ RNase and $50 \mathrm{mg} / \mathrm{mL} \mathrm{PI}$, and incubated at $37^{\circ} \mathrm{C}$ in the dark for $30 \mathrm{~min}$. The DNA content was analyzed using a FACScan flow cytometer (BD Biosciences, San Jose, CA, USA). The population of cells in each cell cycle phase was determined using CellQuest software (BD Dickson, Franklin Lakes, NJ, USA). The sub-G1 population showed apoptosis-associated chromatin degradation.

\subsection{Statistical Analyses}

All experiments were repeated at least three times. The data are expressed as means \pm standard deviation (SD). A statistical analysis was performed using one-way analysis of variance (ANOVA); values of $* p<0.01$ were considered to indicate statistical significance.

\section{Conclusions}

In conclusion, using a global proteomics approach, we identified the nobiletin-regulated protein GRP78 and showed that nobiletin induced ER stress-mediated apoptosis and autophagy in SNU-16 cells via the downregulation of Akt/mTOR signaling. Collectively, nobiletin-induced ER stress plays a crucial role in anticancer activity against SNU-16 gastric cancer cells. These results may promote the development of efficacious therapies combining nobiletin and chloroquine for gastric cancer patients.

Acknowledgments: This research was supported by Basic Science Research Program through the National Research Foundation of Korea (NRF) funded by the Ministry of Education (2013R1A1A2A10012017) and (2013R1A1A2064103).

Author Contributions: Jeong Yong Moon and Somi Kim Cho conceived and designed the experiments, analyzed the data and wrote the manuscript; Jeong Yong Moon performed the experiments and analyzed the data.

Conflicts of Interest: The authors declare no conflict of interest.

\section{References}

1. Nagata, U.; Sakamoto, K.; Shiratsuchi, H.; Ishi, T.; Yano, M.; Ohta, H. Flavonoid composition of fruit tissues of citrus species. Biosci. Biotechnol. Biochem. 2006, 70, 178-192. [CrossRef] [PubMed]

2. Kawabata, K.; Murakami, A.; Ohigashi, H. Nobiletin, a citrus flavonoid, down-regulates matrix metalloproteinase-7 (matrilysin) expression in HT-29 human colorectal cancer cells. Biosci. Biotechnol. Biochem. 2005, 69, 307-314. [CrossRef] [PubMed]

3. Miyata, Y.; Sato, T.; Imada, K.; Dobashi, A.; Yano, M.; Ito, A. A citrus polymethoxyflavonoid, nobiletin, is a novel MEK inhibitor that exhibits antitumor metastasis in human fibrosarcoma HT-1080 cells. Biochem. Biophys. Res. Commun. 2008, 366, 168-173. [CrossRef] [PubMed] 
4. Moon, J.Y.; Cho, M.; Ahn, K.S.; Cho, S.K. Nobiletin induces apoptosis and potentiates the effects of the anticancer drug 5-fluorouracil in p53-mutated SNU-16 human gastric cancer cells. Nutr. Cancer 2013, 65, 286-295. [CrossRef] [PubMed]

5. Zhang, X.; Zhang, K. Endoplasmic Reticulum Stress-Associated Lipid Droplet Formation and Type II Diabetes. Biochem. Res. Int. 2012, 2012, 1-5. [CrossRef] [PubMed]

6. Oyadomari, S.; Mori, M. Roles of CHOP/GADD153 in endoplasmic reticulum stress. Cell. Death Differ. 2004, 11, 381-389. [CrossRef] [PubMed]

7. Puthalakath, H.; O'Reilly, L.A.; Gunn, P.; Lee, L.; Kelly, P.N.; Huntington, N.D.; Hughes, P.D.; Michalak, E.M.; McKimm-Breschkin, J.; Motoyama, N.; et al. ER stress triggers apoptosis by activating BH3-only protein Bim. Cell 2007, 129, 1337-1349. [CrossRef] [PubMed]

8. McCullough, K.D.; Martindale, J.L.; Klotz, L.O.; Aw, T.Y.; Holbrook, N.J. Gadd153 sensitizes cells to endoplasmic reticulum stress by down-regulating $\mathrm{Bcl} 2$ and perturbing the cellular redox state. Mol. Cell. Biol. 2001, 21, 1249-1259. [CrossRef] [PubMed]

9. Matsumoto, M.; Minami, M.; Takeda, K.; Sakao, Y.; Akira, S. Ectopic expression of CHOP (GADD153) induces apoptosis in M1 myeloblastic leukemia cells. FEBS. Lett. 1996, 395, 143-147. [CrossRef]

10. Guertin, D.A.; Sabatini, D.M. Defining the role of mTOR in cancer. Cancer Cell 2007, 12, 9-22. [CrossRef] [PubMed]

11. Tanida, I.; Ueno, T.; Kominami, E. LC3 and Autophagy. Methods Mol. Biol. 2008, 445, 77-88. [PubMed]

12. Wang, M.; Ye, R.; Barron, E.; Baumeister, P.; Mao, C.; Luo, S.; Fu, Y.; Luo, B.; Dubeau, L.; Hinton, D.R.; et al. Essential role of the unfolded protein response regulator $\mathrm{GRP} 78 / \mathrm{BiP}$ in protection from neuronal apoptosis. Cell Death Differ. 2010, 17, 488-498. [CrossRef] [PubMed]

13. Philippova, M.; Ivanov, D.; Joshi, M.B.; Kyriakakis, E.; Rupp, K.; Afonyushkin, T.; Bochkov, V.; Erne, P.; Resink, T.J. Identification of proteins associating with glycosylphosphatidylinositol-anchored T-cadherin on the surface of vascular endothelial cells: Role for Grp78/BiP in T-cadherin-dependent cell survival. Mol. Cell. Biol. 2008, 28, 4004-4017. [CrossRef] [PubMed]

14. Baumeister, P.; Dong, D.; Fu, Y.; Lee, A.S. Transcriptional induction of GRP78/BiP by histone deacetylase inhibitors and resistance to histone deacetylase inhibitor-induced apoptosis. Mol. Cancer Ther. 2009, 8, 1086-1094. [CrossRef] [PubMed]

15. Nemoto, K.; Ikeda, A.; Yoshida, C.; Kimura, J.; Mori, J.; Fujiwara, H.; Yokosuka, A.; Mimaki, Y.; Ohizumi, Y.; Degawa, M. Characteristics of nobiletin-mediated alteration of gene expression in cultured cell lines. Biochem. Biophys. Res. Commun. 2013, 431, 530-534. [CrossRef] [PubMed]

16. Ikeda, A.; Nemoto, K.; Yoshida, C.; Miyata, S.; Mori, J.; Soejima, S.; Yokosuka, A.; Mimaki, Y.; Ohizumi, Y.; Degawa, M. Suppressive effect of nobiletin, a citrus polymethoxyflavonoid that downregulates thioredoxin-interacting protein expression, on tunicamycin-induced apoptosis in SK-N-SH human neuroblastoma cells. Neurosci. Lett. 2013, 549, 135-139. [CrossRef] [PubMed]

17. Ikeda, A.; Miyata, S.; Yokosuka, A.; Mimaki, Y.; Ohizumi, Y.; Degawa, M.; Nemoto, K. Estimation of endoplasmic reticulum stress-inducing ability of nobiletin, a citrus polymethoxyflanonoid, in SK-N-SH human neuroblastoma cells. Fund. Toxicol. Sci. 2014, 1, 169-172. [CrossRef]

18. Calfon, M.; Zeng, H.; Urano, F.; Till, J.H.; Hubbard, S.R.; Harding, H.P.; Clark, S.G.; Ron, D. IRE1 couples endoplasmic reticulum load to secretory capacity by processing the XBP-1 Mrna. Nature 2002, 415, 92-96. [CrossRef] [PubMed]

19. Lee, A.H.; Iwakoshi, N.N.; Glimcher, L.H. XBP-1 regulates a subset of endoplasmic reticulum resident chaperone genes in the unfolded protein response. Mol. Cell. Biol. 2003, 23, 7448-7459. [CrossRef] [PubMed]

20. Tatsuta, T.; Hosono, M.; Miura, Y.; Sugawara, S.; Kariya, Y.; Hakomori, S.; Nitta, K. Involvement of ER stress in apoptosis induced by sialic acid-binding lectin (leczyme) from bullfrog eggs. Int. J. Oncol. 2013, 43, 1799-1808. [PubMed]

21. Edinger, A.L.; Thompson, C.B. Death by design: apoptosis, necrosis and autophagy. Curt. Opin. Cell Biol. 2004, 16, 663-669. [CrossRef] [PubMed]

22. Li, D.D.; Wang, L.L.; Deng, R.; Tang, J.; Shen, Y.; Guo, J.F.; Wang, Y.; Xia, L.P.; Feng, G.K.; Liu, Q.Q.; et al. The pivotal role of c-Jun NH2-terminal kinase-mediated Beclin 1 expression during anticancer agents-induced autophagy in cancer cells. Oncogene 2009, 28, 886-898. [CrossRef] [PubMed] 
23. Oehadian, A.; Koide, N.; Hassan, F.; Islam, S.; Mori, I.; Yoshida, T.; Yokochi, T. Differential expression of autophagy in Hodgkin lymphoma cells treated with various anti-cancer drugs. Acta Med. Indones. 2007, 39, 153-156. [PubMed]

24. Meijer, A.J.; Codogno, P. Autophagy: Regulation and role in disease. Crit. Rev. Clin. Lab. Sci. 2009, 46, 210-240. [CrossRef] [PubMed]

25. Amaravadi, R.K.; Yu, D.; Lum, J.J.; Bui, T.; Christophorou, M.A.; Evan, G.I.; Thomas-Tikhonenko, A.; Thompson, C.B. Autophagy inhibition enhances therapy-induced apoptosis in a Myc-induced model of lymphoma. J. Clin. Investig. 2007, 117, 326-336. [CrossRef] [PubMed]

26. Golovanov, A.P.; Chuang, T.H.; DerMardirossian, C.; Barsukov, I.; Hawkins, D.; Badii, R.; Bokoch, G.M.; Lian, L.Y.; Roberts, G.C. Structure-activity relationships in flexible protein domains: Regulation of rho GTPases by RhoGDI and D4 GDI. J. Mol. Biol. 2001, 305, 121-135. [CrossRef] [PubMed]

27. Yoshida, H.; Haze, K.; Yanagi, H.; Yura, T.; Mori, K. Identification of the cis-acting endoplasmic reticulum stress response element responsible for transcriptional induction of mammalian glucose-regulated proteins. Involvement of basic leucine zipper transcription factors. J. Biol. Chem. 1998, 273, 33741-33749. [CrossRef] [PubMed]

28. Zhang, L.; Hou, Y.; Li, N.; Wu, K.; Zhai, J. The influence of TXNDC5 gene on gastric cancer cell. J. Cancer Res. Clin. Oncol. 2010, 136, 1497-1505. [CrossRef] [PubMed]

29. Burstein, E.; Hoberg, J.E.; Wilkinson, A.S.; Rumble, J.M.; Csomos, R.A.; Komarck, C.M.; Maine, G.N.; Wilkinson, J.C.; Mayo, M.W.; Duckett, C.S. COMMD proteins, a novel family of structural and functional homologs of MURR1. J. Biol. Chem. 2005, 10, 22222-22232. [CrossRef] [PubMed]

30. Sorrells, D.L.; Black, D.R.; Meschonat, C.; Rhoads, R.; De Benedetti, A.; Gao, M.; Williams, B.J.; Li, B.D. Detection of eIF4E gene amplification in breast cancer by competitive PCR. Ann. Surg. Oncol. 1998, 5, 232-237. [CrossRef] [PubMed]

31. Henriksson, M.; Luscher, B. Proteins of the Myc network: Essential regulators of cell growth and differentiation. Adv. Cancer Res. 1996, 68, 109-182. [PubMed]

32. Quinones, Q.J.; de Ridder, G.G.; Pizzo, S.V. GRP78: A chaperone with diverse roles beyond the endoplasmic reticulum. Histol. Histopathol. 2008, 23, 1409-1416. [PubMed]

33. Zhang, L.H.; Zhang, X. Roles of GRP78 in physiology and cancer. J. Cell. Biochem. 2010, 110, 1299-1305. [CrossRef] [PubMed]

34. Kimata, Y.; Kohno, K. Endoplasmic reticulum stress-sensing mechanisms in yeast and mammalian cells. Curr. Opin. Cell Biol. 2011, 23, 135-142. [CrossRef] [PubMed]

35. Fu, Y.; Lee, A.S. Glucose regulated proteins in cancer progression, drug resistance and immunotherapy. Cancer Biol. Ther. 2006, 5, 741-744. [CrossRef] [PubMed]

36. De Ridder, G.; Ray, R.; Misra, U.K.; Pizzo, S.V. Modulation of the unfolded protein response by GRP78 in prostate cancer. Methods Enzymol. 2011, 489, 245-257. [PubMed]

37. Marte, B.M.; Downward, J. PKB/Akt: Connecting phosphoinositide 3-kinase to cell survival and beyond. Trends Biochem. Sci. 1997, 22, 355-358. [CrossRef]

38. Kim, K.W.; Mutter, R.W.; Cao, C.; Albert, J.M.; Freeman, M.; Hallahan, D.E.; Lu, B. Autophagy for cancer therapy through inhibition of pro-apoptotic proteins and mammalian target of rapamycin signaling. J. Biol. Chem. 2006, 281, 36883-36890. [CrossRef] [PubMed]

39. Yap, T.A.; Garrett, M.D.; Walton, M.I.; Raynaud, F.; de Bono, J.S.; Workman, P. Targeting the PI3K-AKT-mTOR pathway: Progress, pitfalls, and promises. Curr. Opin. Pharmacol. 2008, 8, 393-412. [CrossRef] [PubMed]

40. Fujita, E.; Kouroku, Y.; Isoai, A.; Kumagai, H.; Misutani, A.; Matsuda, C.; Hayashi, Y.K.; Momoi, T. Two endoplasmic reticulum-associated degradation (ERAD) systems for the novel variant of the mutant dysferlin: Ubiquitin/proteasome ERAD(1) and autophagy/lysosome ERAD (II). Hum. Mol. Genet. 2007, 16, 618-629. [CrossRef] [PubMed]

41. Shi, S.Q.; Ansari, T.S.; McGuinness, O.P.; Wasserman, D.H.; Johnson, C.H. Circadian disruption leads to insulin resistance and obesity. Curr. Biol. 2013, 23, 372-381. [CrossRef] [PubMed]

42. Zheng, X.; Sehgal, A. AKT and TOR signaling set the pace of the circadian pacemaker. Curr. Biol. 2010, 20, 1203-1208. [CrossRef] [PubMed]

43. He, B.; Nohara, K.; Park, N.; Park, Y.S.; Guillory, B.; Zhao, Z.; Garcia, J.M.; Koike, N.; Lee, C.C.; Takahashi, J.S.; et al. The Small Molecule Nobiletin Targets the Molecular Oscillator to Enhance Circadian Rhythms and Protect against Metabolic Syndrome. Cell Metab. 2016, 23, 610-621. [CrossRef] [PubMed] 
44. Carracedo, A.; Pandolfi, P.P. The PTEN-PI3K pathway: Of feedbacks and cross-talks. Oncogene 2008, 27, 5527-5541. [CrossRef] [PubMed]

45. Wan, X.; Harkavy, B.; Shen, N.; Grohar, P.; Helman, L.J. Rapamycin induces feedback activation of Akt signaling through an IGF-1R-dependent mechanism. Oncogene 2006, 26, 1932-1940. [CrossRef] [PubMed]

46. Mizushima, N. Methods for monitoring autophagy. Int. J. Biochem. Cell Biol. 2004, 36, 2491-2502. [CrossRef] [PubMed]

47. Bjørkøy, G.; Lamark, T.; Brech, A.; Outzen, H.; Perander, M.; Overvatn, A.; Stenmark, H.; Johansen, T. P62/SQSTM1 forms protein aggregates degraded by autophagy and has a protective effect on huntingtin-induced cell death. J. Cell Biol. 2005, 171, 603-614. [CrossRef] [PubMed]

48. Pankiv, S.; Clausen, T.H.; Lamark, T.; Brech, A.; Bruun, J.A.; Outzen, H.; Øvervatn, A.; Bjørkøy, G.; Johansen, T. p62/SQSTM1 binds directly to Atg8/LC3 to facilitate degradation of ubiquitinated protein aggregates by autophagy. J. Biol. Chem. 2007, 282, 24131-24145. [CrossRef] [PubMed]

49. Jain, A.; Lamark, T.; Sjøttem, E.; Larsen, K.B.; Awuh, J.A.; Øvervatn, A.; McMahon, M.; Hayes, J.D.; Johansen, T. p62/SQSTM1 is a target gene for transcription factor NRF2 and creates a positive feedback loop by inducing antioxidant response element-driven gene transcription. J. Biol. Chem. 2010, 285, 22576-22591. [CrossRef] [PubMed]

50. Oakley, B.R.; Kirsch, D.R.; Morris, N.R. A simplified ultrasensitive silver stain for detecting proteins in polyacrylamide gels. Anal. Biochem. 1980, 105, 361-363. [CrossRef]

51. Fernandez, J.; Gharahdaghi, F.; Mische, S.M. Routine identification of proteins from sodium dodecyl sulfate- polyacrylamide gel electrophoresis (SDS-PAGE) gels or polyvinyl difluoride membranes using matrix assisted laser desorption/ionization-time of flight-mass spectrometry (MALDI-TOF-MS). Electrophoresis 1998, 19, 1036-1045. [CrossRef] [PubMed]

Sample Availability: Samples of the compounds are not available from the authors.

(C) 2016 by the authors; licensee MDPI, Basel, Switzerland. This article is an open access article distributed under the terms and conditions of the Creative Commons Attribution (CC-BY) license (http://creativecommons.org/licenses/by/4.0/). 